\title{
The Babol-Kenar (1971) earthquake and the seismotectonics of the Central Alborz (Iran)
}

\author{
J. S. T'Halenko * - M. H. Iranmanesh ** - A. Mohajer-Ashial ***
}

Received on December 23, 1971

Summar. -- 'The Babol-kenar earthquake (9th August, 1971) was a relatively minor event compared to previous catastrophic earthquakes in the Central Alborz mountains of northern Iran. It's study however, is important for the understanding of the seismicity of a resion which has already experienced two large earthquakes during this century and which could be entering a phase of renewed seismic activity. The pattern deduced from the sequence of all recorded earthquakes in the region outlines the structural units of the Central Alborz and suggests the existence of seismotectonic provinces which are alternatively active and quiescent.

Riassunto. - Il ierremoto di Babol-Kenar (9 Agosto 1971) è stato un evento relativamente di scarso rilievo specie se raffrontato a terremoti catastrofici precedenti avvenuti nelle montagne dell Alborz Centrale (I ran settentrionale). Il suo studio, tuttavia, ì importante per conoscere la sismiciti di una regione che in questo secolo ha gia subito due grandi terremoti e che potrebbe quindi entrare in una fase di rinnovata attivita sismica.

Il modello dedotio dalla sequenza di tutti i terremoti regristrati nella regione, traccia i contorni delle unitì strutturali dell'Alborz Centrale e suggerisce l'esistenza di province sismoteitoniche che sono alternativamente attive e tranquille.

\section{1. - Introduction}

The Babol-Kenar earthquake of magnitude $M_{b}=5.2$ occurred on the 9 th August 1971 at $02 \mathrm{~h} 54 \mathrm{~m} 36.7 \mathrm{~s}$ about $150 \mathrm{~km}$ northeast of Tehran in the casplian Province of Mazanderan. The instrumental

* Engineering Seismology, inperial College, Iondon.

** Geological Survey of Iran, Tehran.

*** Geophysics Section, Imperial College, I,ondon. 


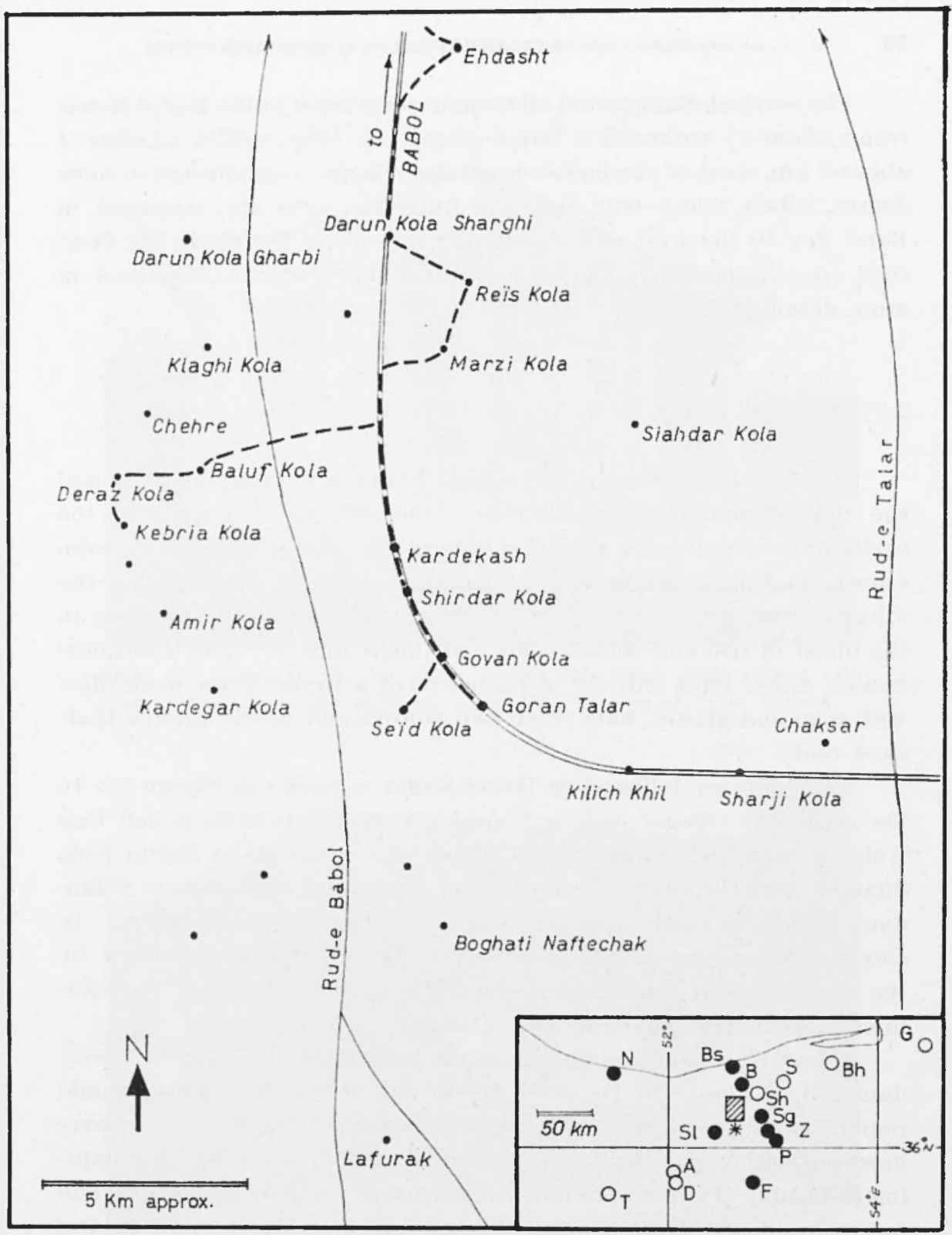

Fig. 1 - Babol.Kenar Epicentral Region (Approximate Sketch). Dashed line indicates anthor's route.

InsERT: Full circle, towns with slight damage. Open circle, towns where shock was strongly felt. Sharled reclangle, Bahol-Kenar epicentral region. Asterisk, instrumental epicentre.

$\mathbf{A}=$ Ab-Ali; $\mathbf{B}=$ Babol; $\mathbf{B h}=$ Behsharh; $\mathbf{B s}=$ Babolsar $; \mathbf{D}=$ Damavand

$\mathbf{F}=$ Firuzkuh; $\mathbf{G}=$ Gorgan $\mathbf{N}=$ Nowshahr; $\mathbf{P} \ldots$ Pol Sefid; $\mathbf{S}=$ Sari;

$\mathbf{S g}=$ Shirgah; $\mathbf{S h}=$ Shahi; $\mathbf{S l}=$ Sangchal; $\mathbf{T}=$ Tehran; $\mathbf{Z}=$ Zirab. 
epicentre was calculated by NOAS to be $36.2 \times 52.7 \mathrm{E}$ and the focal depth $27 \mathrm{~km}$. The (reological Survey of Iran sent a team to the area to define precisely the macroseismic epicentral region and to assess the damage and the seismotectonic implications of the event. The region of maximum damage was found to be at the northermmost limit of the Alborz foothills, south of the town of Babol and at about $15 \mathrm{~km}$ from the instrumental epicentre (Figure 1). About 900 houses in 42 villages suftered damage of some kind (generally light) and one person died and 39 were injured. A summary of the team's visit to the region and conclusions reached is given below.

2. - DAMAGF:

\subsection{General considerations.}

The earthquake felt over most of North-central Iran and the shock was reported as being strong in Tehran, $\Delta b-\Delta l i$, I amavand, Firuzkuh, Gorgan, Behshahr, Nowshahr, as well as in the towns nearer to the epicentre: Babol, Amol, Shahi, Babolsar, Shirgah, Zirab and Pol Sefid (Figure 1). Occasional damage occurred in a few places at a consiclerable distance from the epicentre: at Firuzkuh $(65 \mathrm{~km})$, the Amir Kabir School built of kiln-bricks was slightly damager and one person was injured; at Nowshahr $(120 \mathrm{~km})$, some brick houses developed cracks and glass panes were broken; at $\mathrm{Ab}-\mathrm{Al}(100 \mathrm{~km})$, cracks appeared in one wall of the casino. In this last instance, no other damage could be found either in $\mathrm{Ab}-\mathrm{Ali}$ or in any of the surrounding villages, and it must be assumed that in many of these anomalous cases damage was due to severe weaknesses or Haws in the building or in its foundations.

In localities nearer to the epicentral region, slight damage was more general. In the suburbs of Babol, a minaret collapsed (in BidAbad) and some rows of houses were damaged and glass panes shattered (in Bid-Abad and Raste-Bazar). In Babolsar, one old building was destroyed, the roofs of two houses caved in and several houses developed cracks. In Shirgah, most houses were crackerl, and in the Zivla district near the Post Office some houses partly collapsed. In Sangchal, epicentre of the earthquake of 2nd July 1957 (see next section, seismotectonics), a few houses were crackerl by the reactivation of old lamoslides. 


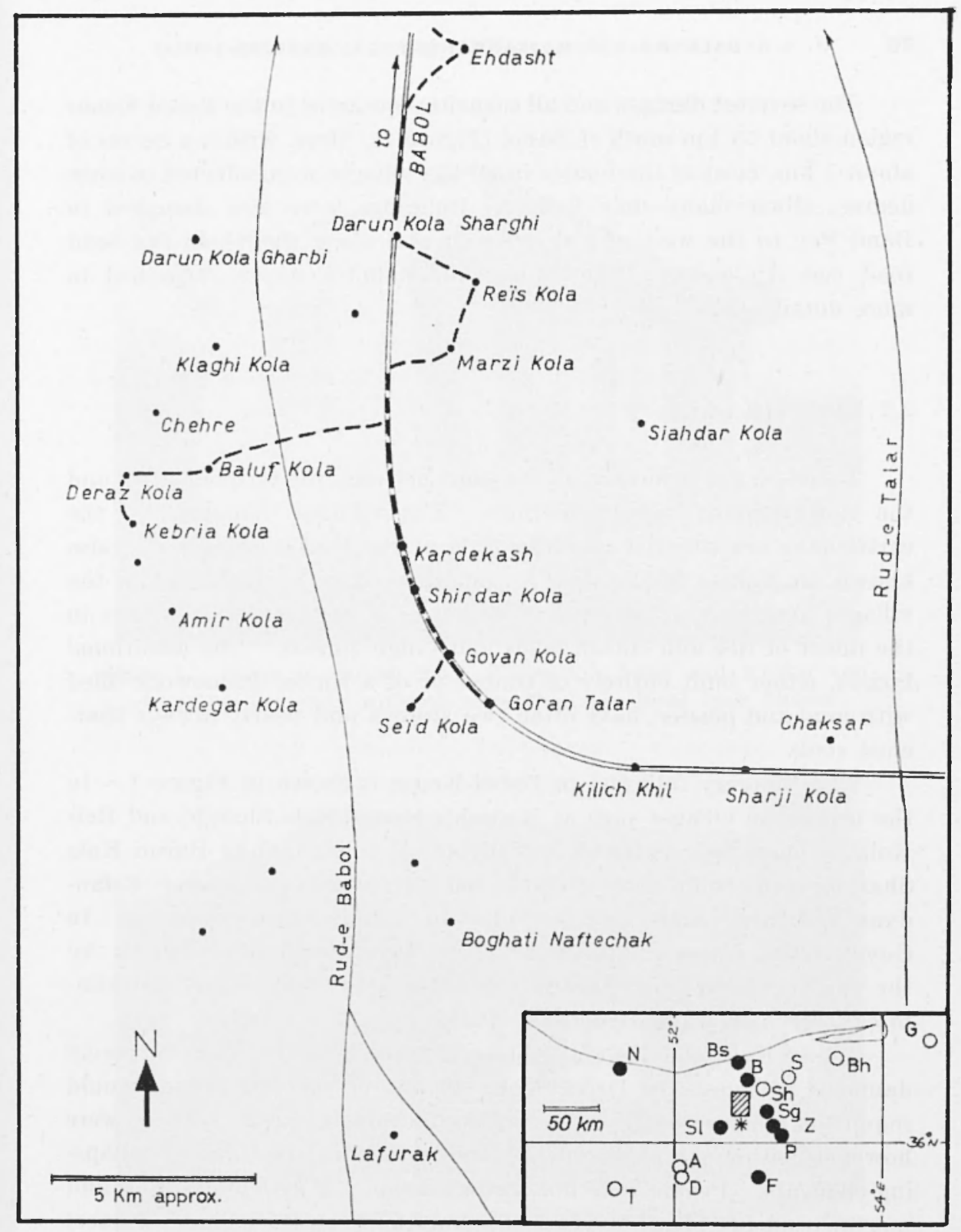

Fig. 1 - Babol-Kenar Epicentral Region (Approximate Sketch). Dasherl line indicates author's route.

Insert: Full circle, towns with slight damage. Open circle, lowns where shock was strongly felt. Shaded rectangle, Bahol-Kena: epicentral region. Asterisk, instrumental epicentre.

$\mathbf{A}=\mathbf{A b} \cdot \mathbf{A l i} ; \mathbf{B}=$ Babol $\mathbf{B h}=$ Belssharh $; \mathbf{B s}=$ Babolsar $\mathbf{D}=$ Damavand;

$\mathbf{F}=$ Firuzkuh; $\mathbf{G}=$ Gorgan $; \mathbf{N}=$ Nowshahr; $\mathbf{P}=$ Pol Sefid $\mathbf{S}=$ Sari;

$\mathbf{S g}=$ Shirgah; $\mathbf{S h}=$ Shahi; $\mathbf{S l}=$ Sangelıal; $\mathbf{T}=$ Tehran; $\mathbf{Z}=$ Zirab. 
The severest damage and all casualties occurred in the Babol-Kenar region about $25 \mathrm{~km}$ south of Babol (Figure 1). Here, within a radius of about $7 \mathrm{~km}$, most of the houses in all the villages were affected to some degree, albeit many only lightly. Buildings were also damaged in Band Pey to the west of Babol-Kenar and along the Shahi-Pol Sefid road (see Appendix). The damage in Babol-Kenar is described in more rletail below.

\subsection{Epicentral region.}

Babol-Kenar is located at the limit between the Caspian plain and the northernmost Alborz foothills. The villages damaged by the earthquake are situated on either sirle of the Rurl-e Babol river (also known as Nahr-e Mianrul). As in other parts of Mazanderan, the villages here have a loosely-knit structure of disconnected hamlets in the mirlst of rice and cotton fields and jungle forests. The traditional houses, either built entirely of timber or of a timber framework filled with mud and plaster, have often two storeys and nearly always thatcheel roofs.

The itinerary followed in Babol-Kenar is shown in Figure 1. In the peripheric villages such as Ehdasht, Darun Kola Sharghi and Reis Kola, damage was scattered and slight. For example in Darm Kola Sharghi, some walls showed cracks but only one house (owner: İsfanlyar Mahrari) partly collapsed due to a foundation weakness. In Govan Kola, where people reported to have been thrown down by the shock (?), the local timber houses resisted better than the kilnbrick and mortar constructions (Plate 1).

Deraz Kola and Kebria Kola are typical of the more severely clamaged villages. In Deraz Kola, 40 out of the 320 houses would require extensive repairs before re-ocempation (Plate 2). There were however neither complete collapses, nor serious injuried due to collapsing elements. People were not thrown down. A well built brick and mortar resilence about 50 years old (and known as Reza Shah's Palace) resisted with only very minor lamage. Its owner confirmed information gathered in the surrounding villages, that the last strong earthquake in the region was felt in 1935 , and that the 1957 earthquake of was much weaker (see section on seismotectonics). The duration of severe shaking in 1971 was estimated between 6 and 8 seconds from interviews reconstructing the movements of observers during the event. 


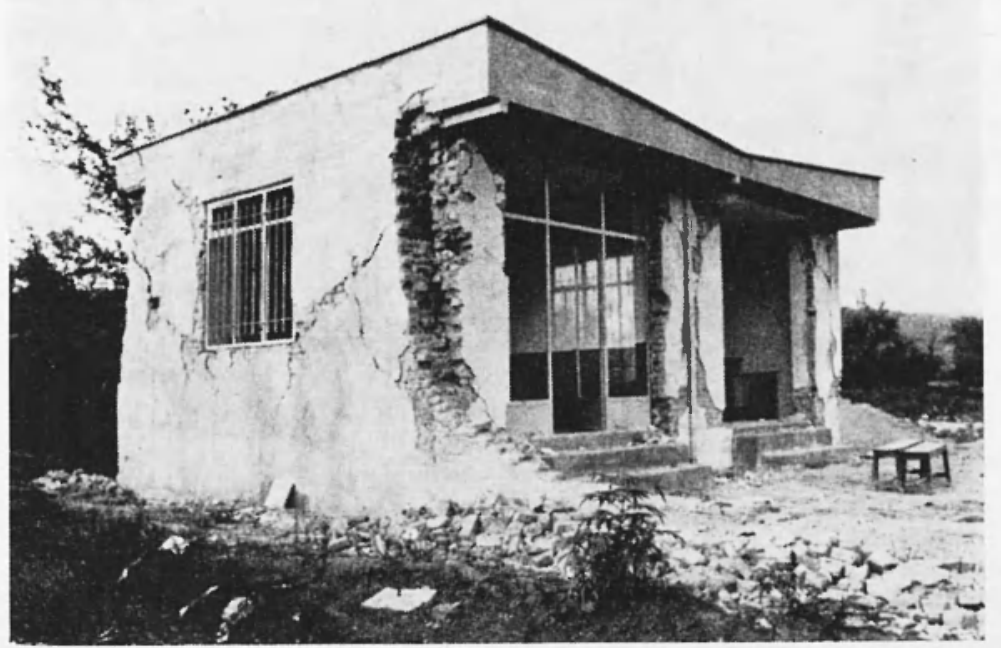

Plate 1 - Shopss in Govan Kola. These kiln-brick and mortar constructions generally suffered more than the local type houses.

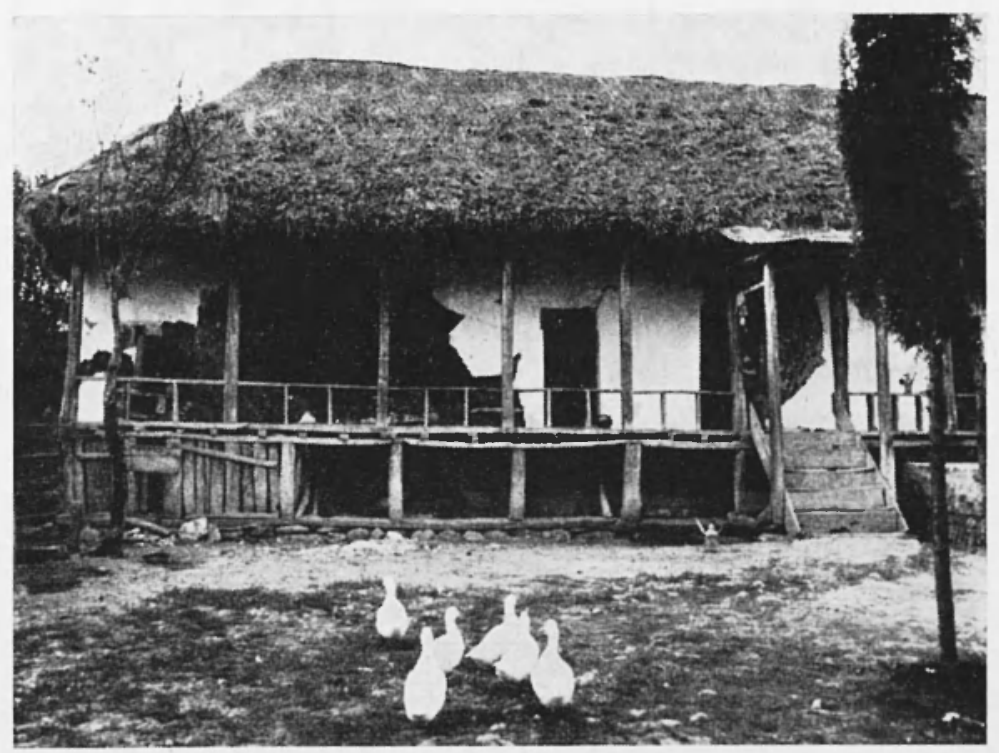

Plate 2 - Local type house in Deraz Kola. All inner and outer walls will have to be rebuilt, but the timber framework and roof will only neell uninor repairs. 


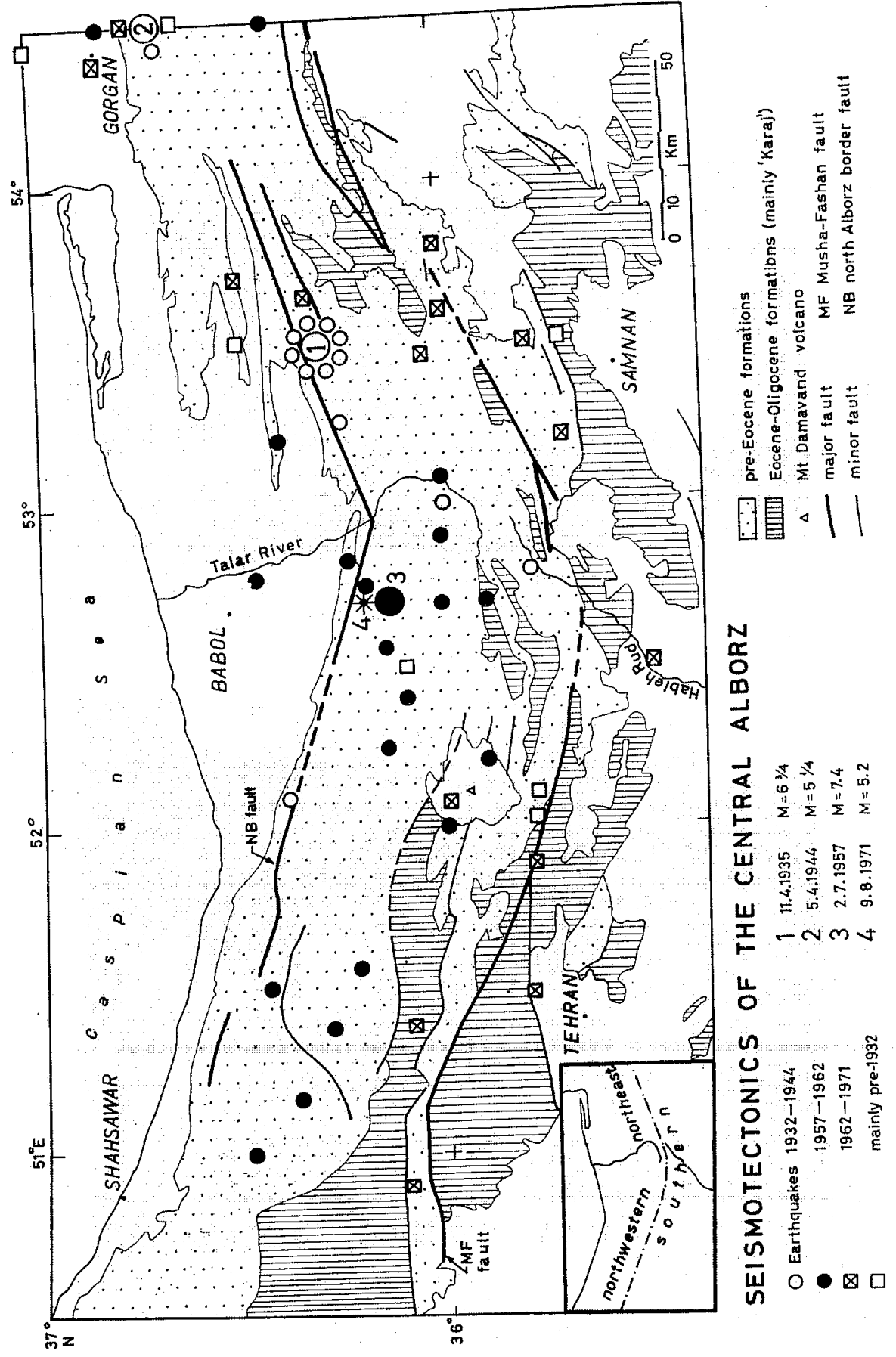


It is of interest to note that the two-storey talar (*) structure showed no sign of damage or strain by this earthquake but were reported by locals as swaying violently during the earthquake of 1935 .

In conclusions, local timber-framed houses were severely cracked only if they were old or if they har weak foundations. No complete collapse was seen and partially collapser houses were the exception. Well-built local houses resisted with much less damage than the few small kiln-brick and mortar houses.

No evidence was found for ground fracturing of any type.

\section{3. - SeIsuotectovics}

\subsection{Previous catastrophic earthqualies}

Two earthquakes are known to have caused wide-sprear destruction during this century in the Central Alborz. The first one ( $n^{\circ} 1$ in Fig. 2) occurred on the 11 th $A$ pril, 1935 and was assigned a magniturle of $6.75{ }^{(4)}$. Little is known of the resulting damage, except that 27 villages were destroyed and about 400 people were killed. The second earthquake, of magnitude 7.4 ( $n^{\circ} 3$ in Fig. 2), occurred on the 2 nd July, 1957 and caused about 1000 deaths. Maximum damage was in the Sangchal region (Fig. 1) even though extensive destruction accentuated by landslides and rockfalls occurred along the Hera\% and Talar valleys. Both earthquakes were followed by strong aftershocks: in 1935 these were confined to the eastern part of the range, whereas in 1957 they nearly all took place in the west.

A smaller shock at the eastern limit of the area sturlied here (n ${ }^{\circ}$ 2 in Fig. 2) ramager (Gorgan on the 5th April, 1944, killing 20 people in the town and surrounding villages.

\subsection{Sequence of earthqualies}

When the chronology of earthquakes in the Central Alborz of magniturle greater than 4 is consirlerer, three distinct regions can be delineated. From 1932 (May) to 1944 (November), all earthquakes

(*) Cage-like rooms set on wooden piles and raised by about 4 metres from the ground. They are used in Summer as sleeping quarters. 
occurred on the northern (Caspian) flank and east of the Talar and Iableh Rud valleys. From 1957 (May) to 1962 (August) earthquakes were also locater on the northern flank, but west of the Talar-IIableh Rud valleys (*). From 1962 (September) onwards, these two regions were quiescent, almost all events being confined to the southern (Tehran-Semnan) flank of the range. The three seismicity regions, Northeastern, Northwestern and Sonthern, can be deduced from Figure 2 which shows all the instrumentally determined epicentres in the Central Alborz.

The Babol-Kenar earthquake of 1971 is the first event to diverge appreciably from this pattern. It occurred in the Northwestern seismicity region, whereas the great majority of shocks from September 1962 up to August 1971 were situater in the Southern region. Its instrumental epicentre ( ${ }^{\circ} 4$ in Fig. 2) is slightly north of the 1957 epicentre, the macroseismic data in 1957 as well as in 1971 being in agreement with these positions. Even though the intensity at the epicentre was far greater in 1957 than in 1971 , the areas of minimum damage were similar, all distant locations having suffered minor lamage in 1971 being within the isoseismal VI (MIM) of the earthquake of 1957.

\subsection{Seismotectonic provinees.}

The differentiation of a northern and sonthern region is a structural characteristic of the Alborz throughout its geological history. An early range existed already in the Paleogene, later developing into a barrier separating the Caspian depression in the north from the Neogene basins of C'entral Iran in the south $(7,8)$. Different regimes of sedimentation and tectonic movements on either side of this barrier are known for various geological periods, and are perhaps most striking for the Eocene-Oligocene time. Eocene sedimentation and voleanism producing the "Green Berts" or "Karaj Formation" are widespread and up to $400 \mathrm{~m}$ thick on the southern flank of the Alborz, but entirely missing in the north. The northern limit of these Eocene formations coincirles approximately with the northern limit of the Southern seismicity region seen in the previous section (Fig. 2).

Several major fault zones run parallel to the general trend of the range, subdivirling it into structural regions $(1,2,3,6)$; There are some indi-

(*) From November 1944 to May 1957, with only 2 exceptions, no earthquakes were recorded for the region under study. 
cations that the southern Musha-Fashan fault zone and the zone at the northern borker of the range may be active. Whether they are funclamental to the seismicity of the Central Alborz it is not possible to determine with the limited rata available at present. Probably of greater significance to the seismotectonics of the region is the sudden change in the structural directions from NW-SE in the west to NE-SW in the east. The major tectonic event of the Quaternary, the creation of the Damavand Volcano, is located near this hinge, and the delineation of a Northeastern and a Northwestern region on the basis of earthquake sequence indicates that at present seismicity is also controlled by this change in structural directions.

The correspondence between the seismicity seen in the previous section and the regional tectonics suggests that the Northwestern, Northeastern and Southern regions are seismotectonic provinces which, to a certain extent, act independantly one from another.

\subsection{Conclusions}

The structural subdivision recognized by geologists for the Central Alborz, i.e. the northern and southern flanks, are also seismicity units on the basis of the chronological sequence of recorderl earthquakes. Furthermore, the larger eurthquakes are concentrated in the region where the structural trend changes abruptly from NIV to NE. The three seismotectonic provinces which can thus be defined, the Northeastern the Northwestern and the Southern Seismotectonic Provinees, have been, since about 1900 , alternatively active and quiescent. The Babol-Kenar earthquake of the 9th August 1971, occurring in a province which has been quiescent since the last aftershocks of the earthquake of 1957 , may signify that the northern flanc of the Alborz is entering a new phase of seismic activity.

\section{ACKNOW1,EDGEMENT'S}

The field work reported here was undertaken as part of a joint project between the Geological Survey of Iran and the Engineering Seismology section, Imperial College, Ijondon, the latter being supported for this work by a grant from the National Environmental Research Council, Isondon. 


\section{REFERENCES}

(1) Allenbach 1'., 1966. - Geologie und Petrographie des Damavand und seiner Umgebung (Zentral-Elburz), Iran. "Mitt. Gool. Inst. Eidgen. Tech. Hochshuk Univ. Zurich", N.F. 63, pp. 144.

(2) Assereto R., 1966. - Geological map of upper Djajerud and Lar Valleys (Central Elburz, Iran). Inst. Geol. Univ. Milano, Serie G., Publ., No 232, pp. 86.

(3) GAnsser A. and HuBer, H., 1962. - Geological observations in the Central Elburz, Iran. "Schw. Min. Petr. Mitt.", 42 (2), pp. 583-630.

(4) Gutenderg B. and Richter C. F., 1954. - Seismicity of the Earth, 2nd Ed. Princeton, New Jersey: Princeton University Press.

(5) National Oceanic and Atmospineric Administration (NOAa): Preliminary determination of epicentres.

${ }^{(8)}$ Steiger R., 1966. - Die Geologie der West-Firuzkuh Area (Zentral Elburz, Iran.) “Mitt. Geol. Inst. Eidgen. Tech. Hochschule Univ. Zurich", N.F. 68, pp. 145.

(7) Stocklin J., 1968. - Structural history and tectonics of Iran. "Am. Assoc. Petrol. Geol., Bull." 52 (7), 1229-1258.

(8) Stockin J. and Nabavi M., 1968. - Summary of the geology of the Alborz Mountains and Iranian Azarbaijan. "Int. Session on 'Tect. Maps of Europe, Near and Hiddle East, Baku. 1968". 